\author{
반추미생물 분석에 의한 Chromium-methionine Chelate의 반추위 \\ By-pass율 추정 \\ 김창혁· 박병기· 박정금·김현숙·성경일·신종서·오상집 \\ 강원대학교 동물자원공동연구소
}

\title{
Estimation of Rumen By-pass Rate of Chromium-methionine Chelates by Ruminal Bacteria Analysis
}

\author{
C. H. Kim, B. K. Park, J. G. Park, H. S. Kim, K. I. Sung, J. S. Shin and S. J. Ohh \\ Institute of Animal Resources, Kangwon National University
}

\begin{abstract}
The study was designed to estimate the in vitro rumen by-pass rate of both chromium methionine chelate as an organic supplement and $\mathrm{CrCl}_{3}$ as an inorganic supplement. Rumen by-pass rates of the supplements were evaluted by comparing ruminal metabolites in rumen fluid and $\mathrm{Cr}$ and methionine contents in the body of ruminal microorganism.

For in vitro digestion examination, basic nutrients for ruminal microbes were supplied with $7 \mathrm{~g}(\mathrm{DM})$ of feed, $2 \mathrm{~g}$ of rice straw, and $2 \mathrm{~g}$ of corn silage per each incubation jar. Three treatments including Control(no supplementation of $\mathrm{Cr}$ ), $\mathrm{T} 1\left(1000 \mathrm{ppb}\right.$ supplementation of $\left.\mathrm{CrCl}_{3}\right)$ and $\mathrm{T} 2$ (chromium methionine chelate supplementation equivalent to $1000 \mathrm{ppb}$ of $\mathrm{Cr}$ content) were prepared with five replications per each treatment.

$\mathrm{pH}$ of $\mathrm{T} 2$ was lower than that of Control and T1 regardless of incubation time. Ammonia content was higher in T2 than in Control and T1 during first 6 hours of incubation. However, the ammonia content in Control was remained low after 6 hours. Total volatile fatty acids (VFA) content in control was increased constantly as incubation time was extended. Therefore, VFA content in T1 and T2 were significantly lower $(\mathrm{P}<0.05)$ than those of Control. Dry matter recovery rate by ruminal microorganism was the lowest in $\mathrm{T} 1$, however ruminal microbial population was increased most efficiently in $\mathrm{T} 2$ during 12 hours of in vitro incubation. $\mathrm{Cr}$ concentrations in the body of ruminal microbes were not different $(\mathrm{P}>0.05)$ between Control and $\mathrm{T} 2$, but it was significantly high in $\mathrm{T} 1(\mathrm{P}<0.05)$. Contents of methionine and cystine in ruminal microbes also were not different between Control and T2 $(\mathrm{P}>0.05)$, but it was relatively low in T1.

Based on the above results, the chromium methionine chelate was believed to by-pass rumen and could remain intact until it reaches small intestine compared to inorganic chromium. This results implies that chromium methionine chelate could be more effective to function in the small intestine of ruminant animals. (Key words : Chromium, Ruminal microbe, Methionine, Chromium-methionine chelate, In vitro)
\end{abstract}

$\begin{array}{cl}\text { I. 서 론 } & \begin{array}{c}\text { 용에 대한 관심이 높아지고 있는 실정이다. 특 } \\ \text { 히 가축의 체내에서 생체조절에 관여하는 광물 }\end{array} \\ \text { 최근, 동물의 성장 촉진, 사료효율 개선 및 } & \text { 질의 경우 일반적인 사료급여 방법을 통해서는 } \\ \text { 기능성 육의 생산을 목적으로 미량광물질의 이 } & \text { 급여효율이 떨어질 뿐만 아니라 체내 이용율 }\end{array}$

본 연구는 1999년도 한국학술진흥재단의 대학부설연구소 지원과제(KRF-01-005-G20007)로 수행한 연구임.

Corresponding author:Chang-Hyeug, Kim, Institute of animal resources, Kangwpn National University, Chuncheon, 200-701, Korea, Tel : 033-250-7693. 
또한 낮은 특성으로 인해 최근에는 미량 광물 질의 급여효율 및 체내 이용성을 높이기 위한 방안으로 미량광물질에 대한 유기태화 기술이 활용되고 있다(Jeffrey와 Fisher, 1990).

Chromium(이하 $\mathrm{Cr}$ )은 가축의 체내 영양소 대 사에 관여하여 육조성분을 조절하는 기능이 있 는 것으로 보고된 바 있다(Schwartz와 Mertz, 1959). 즉, glucose tolerance factor(GTF)의 구성 성분으로서 insulin의 기능 활성(Schwartz와 Mertz, 1957)에 관여하며, 콜레스테롤 항상성 유지(Evans, 1989), HDL-cholesterol 증가(Evans, 1989), 면역기능 강화 등(Schwartz와 Mertz, 1959; Steele 등, 1977, 1982; Anderson, 1987; Evans, 1989; Chang과 Mowat, 1992; MoonsieShageer와 Mowat, 1993)의 기능을 하는 것으로 보고된 바 있다. 이상에서 언급한 바와 같이 $\mathrm{Cr}$ 은 체내에서 반드시 필요로 하는 광물질이지 만, $\mathrm{Cr}$ 자체가 체내 이용성이 매우 낮은 관계 로 picolinate, nicotinate, EDTA, yeast, amino acid(methionine, alanine) 등 유기물을 결합대상 (ligand, 이하 리간드)으로 chelate $\mathrm{Cr}$ 을 제조하 여 이용하고 있다(Mertz와 Roginski, 1969; Votava 등, 1973).

몇몇 연구자들에 의해 일부 축종에서 실시되 었던 chelate $\mathrm{Cr}$ 의 첨가 효과에 대해 살펴보면, 브로일러(Anderson, 1987) 및 돼지(Page 등, 1993)의 경우 chelate $\mathrm{Cr}$ 을 첨가하게 되면 증체 량 및 사료효율이 개선되며, chelate $\mathrm{Cr}$ 은 체내 에서 단백질 합성, 핵산 및 지질대사와도 밀접 한 관련이 있는 것으로 보고된 바 있다. 한편, Kegley 등 (1997)은 육우에 chelate $\mathrm{Cr}$ 을 첨가한 결과 chelate $\mathrm{Cr}$ 의 첨가 급여는 면역기능을 증 가시켜 질병을 예방할 뿐만 아니라 수송 스트 레스로 인한 경제적인 손실도 감소시켜준다고 보고하였으나, 반추동물의 경우 단위동물과는 달리 증체율 및 사료효율의 개선효과는 기대할 수 없는 것으로 보고된 바 있다 (Swanson 등, 2000).

단, 아쉬운 점은 단위 동물에 비해 반추동물 의 경우 chelate $\mathrm{Cr}$ 의 급여에 따른 생산성 증진 효과 및 생리적인 특성 구명이 상대적으로 미 흡한 실정인데, 이는 반추동물을 대상으로 한 chelate $\mathrm{Cr}$ 의 실험이 상대적으로 부족한데 일차 적인 원인이 있으며, 2차적인 원인으로는 chelate $\mathrm{Cr}$ 의 첨가에 따른 반추 미생물에 의한 발효특 성 및 소장으로의 by-pass 여부에 대한 검토가 이루어지지 않았기 때문에 chelate $\mathrm{Cr}$ 의 반추동 물을 대상으로 한 활용에 있어서 제한 요인으 로 작용하고 있는 것으로 사료된다.

따라서 본 연구는 $\mathrm{Cr}$ 을 유기태화 하기 위하 여 methionine으로 chelate한 Cr-methionine chelate (이하 크라민 ${ }^{\circledR}$, Inno-Bio, Korea)의 첨가가 in vitro 반추위 발효특성에 미치는 영향을 조사하 고 반추위액 중에서 크라민 ${ }^{\circledR}$ 의 용해성 및 반추 미생물 집단에 의한 크라민 ${ }^{\circledR}$ 의 흡수여부를 평 가하여 chelate $\mathrm{Cr}$ 의 이용성, 안정성 및 by-pass 여부를 간접적으로 증명하고자 실시하였다.

\section{II. 재료 및 방법}

\section{1. 공시동물 및 사양관리}

본 시험에서는 공시동물로 반추위 cannula가 장착된 한우 암소 $(400 \mathrm{~kg})$ 를 이용하였으며, 사료 급여는 체중의 $1.5 \%$ 수준으로 조사료인 호밀건 초와 시판 배합사료의 비율을 50:50으로 하여 1일 2회(09:00 및 18:00) 급여하였고, 물은 자유 음수토록 하였다. 실험은 예비시험기간 6 일과 본 시험 1 일로 반복 실시하였다. 급여한 농후 사료의 구체적인 배합비는 Table 1 과 같다.

\section{2. 시험구 처리}

In vitro 배양시험은 one batch in vitro incubator (model : Ankom Technology-DAISY II, USA)를 이용하여 실시하였으며, 배양 처리구는 $\operatorname{jar}$ (배양 용기)를 이용하였다. Jar 당 반추미생물의 기초 영양소로 시중에 유통되고 있는 배합사료는 20 mesh 이하로 분쇄하여 건물기준으로 $7 \mathrm{~g}$, 볏짚 $2 \mathrm{~g}$ 및 Corn silage $2 \mathrm{~g}$ 씩 동일하게 첨가한 후 부형제만을 첨가한 대조구(control), $\mathrm{CrCl}_{3}$ 를 1000 $\mathrm{ppb}$ 첨가한 $\mathrm{T} 1$ 구 및 $\mathrm{Cr}$ 함량이 $1000 \mathrm{ppb}$ 가 되 도록 크라민 ${ }^{\circledR}$ 을 첨가한 $\mathrm{T} 2$ 구로 총 3 처리구를 두었으며, 처리 당 5 반복으로 시험을 수행하였 
Table 1. Feed ingredient and chemical composition of a fermulated mixture used for incubation

\begin{tabular}{lc}
\hline Ingradients & $\%$ \\
\hline \hline Corn & 55.0 \\
Wheat & 15.0 \\
Defatted rice bran & 8.0 \\
Corn gluten feed & 5.0 \\
Soybean meal & 10.0 \\
Molasses & 0.2 \\
Limestone & 2.0 \\
Salt & 0.5 \\
Calcium-phosphate & 1.3 \\
Vit.-min. mixture ${ }^{1)}$ & 1.0 \\
\hline Calculated chemical composition & \\
\hline Crude protein & 15.12 \\
TDN & 74 \\
Calcium & 1.16 \\
Phosphrous & 0.75 \\
\hline Vitamin-mineral mixture: Vitamin A & $3000 \mathrm{IU} ;$ \\
Vitamin D 6000 IU; Vitamin E 30 IU; Cu 25 m; \\
Fe 150 mg; Zn 200 mg; Mn 100 mg; Co $0.5 \mathrm{mg;} \mathrm{I}$ \\
1.5 mg.
\end{tabular}

다(Table 2).

3. Rumen inoculum 및 in vitro 배양액의 준비

In vitro 배양 시험에 사용된 반추위액의 채 취는 반추위 cannula가 장착된 한우 암소 $(400$ $\mathrm{kg}$ )의 반추위 cannula를 통해 오전 사료 급여전 에 반추위액과 고형물을 채취한 후 4겹의 cheese cloth를 통해 여과하여 $2,000 \mathrm{ml}$ 를 채취하였으 며, 채취한 위액은 미리 $39^{\circ} \mathrm{C}$ 로 예열되고 $\mathrm{O}_{2}$ free- $\mathrm{CO}_{2}$ gas가 충진된 용기에 담고 재차 $\mathrm{O}_{2}$ free- $\mathrm{CO}_{2}$ gas를 30 초간 주입한 후 밀폐하여 혐 기적인 조건을 유지하였다. 채취된 반추위액은 30 분 내로 실험실로 운반한 후 in vitro 배양시 험을 위한 inoculum으로 사용하였다.

In vitro 배양액은 rumen inoculum $400 \mathrm{ml}$ 를 미리 제조된 인공타액(buffer solution A 및 B)
Table 2. Composition of rumen buffer solutions for in vitro incubation

\begin{tabular}{lrc}
\hline \multicolumn{1}{c}{ Components } & & Unit \\
\hline \hline Buffer solution A: & & \\
$\mathrm{KH}_{2} \mathrm{PO}_{4}$ & 10.0 & $\mathrm{~g}$ \\
$\mathrm{MgSO}_{4} \cdot 7 \mathrm{H}_{2} \mathrm{O}$ & 0.5 & $\mathrm{~g}$ \\
$\mathrm{NaCl}$ & 0.5 & $\mathrm{~g}$ \\
$\mathrm{CaCl}_{2} \cdot 2 \mathrm{H}_{2} \mathrm{O}$ & 0.1 & $\mathrm{~g}$ \\
Urea(regent grade) & 0.5 & $\mathrm{~g}$ \\
Distilled water & 1,000 & $\mathrm{ml}$ \\
\hline Buffer solution B: & & \\
$\mathrm{Na}_{2} \mathrm{CO}_{3}$ & 15.0 & $\mathrm{~g}$ \\
$\mathrm{Na}_{2} \mathrm{~S} \cdot 9 \mathrm{H}_{2} \mathrm{O}$ & 1.0 & $\mathrm{~g}$ \\
$\mathrm{Distilled} \mathrm{water}$ & 1,000 & $\mathrm{ml}$ \\
\hline
\end{tabular}

$1,600 \mathrm{ml}$ 와 혼합하여 제조하였다. 인공타액은 Table 3 과 같은 비율로 buffer solution $\mathrm{A}$ 와 $\mathrm{B}$ 로 구분하여 각각 제조한 후 시험개시 전에 $\mathrm{A}$ 용 액 $1,330 \mathrm{ml}$ 과 $\mathrm{B}$ 용액 $266 \mathrm{ml}$ 를 동시에 in vitro 배양 $\mathrm{jar}$ 에 넣고 혼합하여 $\mathrm{pH}$ 가 6.8 이 되도록 조정하였으며, $39^{\circ} \mathrm{C}$ 까지 예열하여 사용하였다. 한편, rumen inoculum 접종시에는 $\mathrm{O}_{2}$ free- $\mathrm{CO}_{2}$ gas를 30 초간 충진하여 배양 jar내의 공기를 배 제하였으며, 그 후 $39^{\circ} \mathrm{C}$ 에서 1 시간 동안 예비 배양을 실시하여 안정화 시킨 후 시험에 이용 하였다.

\section{4. 조사항목 및 분석방법}

(1) 배양액 내 $\mathrm{pH}$ 및 암모니아 농도 측정 In vitro 배양 $0,3,6,9$ 및 12 시간별로 각각 배양액 $5 \mathrm{ml}$ 를 채취한 즉시 $\mathrm{pH}$ 를 측정하고, $4^{\circ} \mathrm{C}$ 에서 $3,000 \times \mathrm{g}$ 로 5 분간 원심 분리한 후 상층 액을 10 배 희석하여 자동수질분석기(Quikchem 8000, USA)로 배양액내 암모니아 농도를 측정 하였다.

(2) 휘발성 지방산(VFA) 농도

배양액의 VFA 농도는 실험설계에 따라 매 시간대별로 $5 \mathrm{ml}$ 의 배양액을 채취한 후 $20 \%$ 의 
Table 3. Experimental design for in vitro trial

\begin{tabular}{lccc}
\hline \multirow{2}{*}{ Items } & \multicolumn{3}{c}{ Treatment } \\
\cline { 2 - 4 } & Control & T1 & T2 \\
\hline Basal feed(DM) $(\mathrm{g})$ & 7 & 7 & 2 \\
Corn silage(DM) $(\mathrm{g})$ & 2 & 2 & 2 \\
Rice straw(DM) $(\mathrm{g})$ & 2 & 2 & 1,000 \\
Cr content $(\mathrm{ppb})$ & - & 1,000 & \\
\hline
\end{tabular}

$\mathrm{T} 1: \mathrm{CrCl}_{3}, \mathrm{~T} 2$ : Chromium-methionine chelate.

metaphosphate $1 \mathrm{ml}$ 및 포화 $\mathrm{HgCl}_{2} \quad 0.5 \mathrm{ml}$ 를 첨 가한 후 $4{ }^{\circ} \mathrm{C}$ 에서 $4,000 \times \mathrm{g}$ 로 5 분간 원심 분리 하여 상층액을 취한 후 gas chromatography (Shimadzu GC-17A, Japan)를 이용하여 휘발성 지방산 농도를 측정하였다. 휘발성 지방산 측 정에 이용된 column은 HP-Innowaw (CrossLinked PEG) $30 \mathrm{~m} \times 0.32 \mathrm{~mm} \times 0.5 \mu \mathrm{m}$ (HP Part No. $19091 \mathrm{~N}-213$ ) 이었으며, 측정조건은 inject port 온도 $200^{\circ} \mathrm{C}$, column 온도 $150^{\circ} \mathrm{C}$, detector 온도 $220^{\circ} \mathrm{C}$ 및 $5^{\circ} \mathrm{C} / \mathrm{min}$ 의 column temperature programing에 따라 실시하였다. 또한 헬륨(He)gas(carrier gas) 유입량은 $1 \mathrm{ml} / \mathrm{min}$ 으로 하고, 수소 $\left(\mathrm{H}_{2}\right)$ gas 및 산소(air) 흐름속도는 각각 $30 \mathrm{ml} / \mathrm{min}$ 및 300 $\mathrm{ml} / \mathrm{min}$ 이었으며, 시료 주입량은 $1 \mu l$ 로 하였다.

(3) 총 미생물의 분리

In vitro 배양 $0,3,6,9$ 및 12 시간대별로 각 각 $200 \mathrm{ml}$ 의 배양액을 채취한 후 사료 입자에 부착되어 있는 총 미생물을 분리하기 위하여 $\mathrm{O}_{2}$ free- $\mathrm{CO}_{2}$ gas를 주입하며 homogenizer로 3분 간 3회를 교반한 다음 $\mathrm{O}_{2}$ free- $\mathrm{CO}_{2}$ gas를 연속 적으로 주입하며 4겹의 cheese cloth로 여과하여 총 미생물 분리를 위한 시료로 사용하였다. 총 미생물의 분리는 Shultz와 Shultz(1970)의 tungstic acid 침전법에 의해 분리하였는데, 위액 $20 \mathrm{ml}$ 에 $1.07 \mathrm{~N} \mathrm{H}_{2} \mathrm{SO}_{4} 5 \mathrm{ml}$ 및 $10 \%$ sodium tungstate $5 \mathrm{ml}$ 를 분주하고 교반하였으며, 교반된 시료는 4 시간 이상 정치시킨 후 $200 \times \mathrm{g}$ 에서 20 분 동안 원심 분리하여 상층액을 제거하였다. 침전물은 원심분리를 통해 증류수: $\mathrm{H}_{2} \mathrm{SO}_{4}$ : Sodium tungstate (4:1:1) 용액으로 2 회 세척한 다음 동결 건조 하여 분석 전까지 $4^{\circ} \mathrm{C}$ 에서 냉장 보관하였다.
(4) 균체의 $\mathrm{Cr}$ 및 아미노산 농도 분석

미생물체에 함유된 $\mathrm{Cr}$ 농도는 미생물 균체를 건식법으로 $600^{\circ} \mathrm{C}$ 에서 24 시간 동안 회화 후 3 차 증류수로 10 배 희석하여 ICP (LEEMAN PS950, USA)를 이용하여 분석하였다. 또한 미 생물 균체의 아미노산 함량은 Mason 등 (1980) 의 방법에 따라 미생물 시료를 전처리 하여 HPLC (Waters 510 Pump; Waters ${ }^{\mathrm{TM}}$ Automated Gradient Controller; Waters ${ }^{\mathrm{TM}} 486$ Tunable Absorbance Detector; Waters Temporature Control Module, $\mathrm{USA}$ )를 이용하여 분석하였다.

\section{5. 통계분석}

본 실험에서 얻어진 결과들은 $\mathrm{SAS} @, 8.1$ package/ PC(1990)를 이용하여 일반선형 모형 (GLM)으로 분산분석을 실시한 후 처리간 평균 의 유의성 검증을 Pair-difference의 방법에 의해 $0.05 \%$ 수준에서 유의성을 검증하였다.

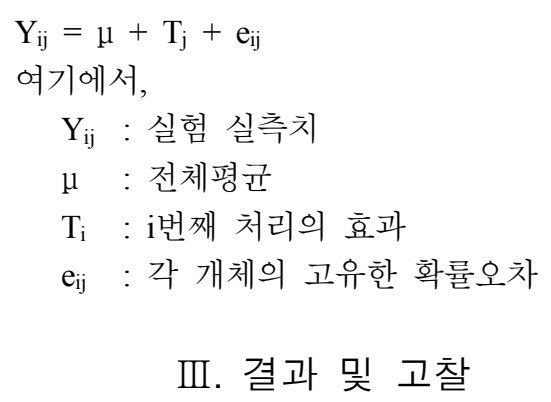

일부 반추위 박테리아가 가지고 있는 많은 효소는 $\mathrm{pH}$ 변화에 민감하기 때문에 미생물의 세포내 $\mathrm{pH}$ 는 거의 중성으로 유지된다. 만일 $\mathrm{pH}$ 
가 낮아지게 되면 세포 외부의 $\mathrm{H}^{+}$농도가 증가 하고 세포내로 $\mathrm{H}^{+}$가 유입되기 때문에 박테리아 는 세포내 $\mathrm{pH}$ 를 거의 중성으로 유지하기 위해 세포 외부로 $\mathrm{H}^{+}$를 수송하기 위한 추가적인 $\mathrm{ATP}$ 를 소비해야만 한다(박 등, 2002). 또한 ATP hydrolysis로부터 파생된 ATP 혹은 에너지 는 양자를 이동시키기에 불충분하게 되고 세포 내의 $\mathrm{pH}$ 가 떨어지고 이는 효소는 불활성화를 유도하여 세포의 사멸을 초래하기 때문에 첨가 물에 따른 배양액내 $\mathrm{pH}$ 를 조사는 기본적으로 수행되어야 한다.

무기태 3 가 $\mathrm{Cr}$ 인 $\mathrm{CrCl}_{3}$ 및 chelate $\mathrm{Cr}$ 인 크라 민 ${ }^{\circledR}$ 의 첨가에 따른 in vitro 배양액의 $\mathrm{pH}$ 변화 는 Table 4에 나타낸 바와 같다. In vitro 배양 3 시간의 대조구(Control), $\mathrm{T} 1\left(\mathrm{CrCl}_{3}\right)$ 및 $\mathrm{T} 2$ (크라 민 ${ }^{\circledR}$ )구의 배양액내 $\mathrm{pH}$ 는 각각 $6.61,6.66$ 및 6.59 로 나타나 비록 통계적인 유의성은 인정되 지 않았으나, 대조구 및 $\mathrm{T} 1$ 구에 비해 $\mathrm{T} 2$ 에서 배양액내 $\mathrm{pH}$ 가 낮은 경향을 보였다. 또한 이후 배양시간이 경과함에 따라 처리에 관계없이 배 양액내 $\mathrm{pH}$ 가 지속적으로 낮아지는 경향을 보 였으며, 배양 3 시간과 마찬가지로 대조구 및 $\mathrm{T} 1$ 구에 비해 $\mathrm{T} 2$ 구에서 배양시간에 관계없이 배양액내 $\mathrm{pH}$ 가 낮은 경향을 보였다. 이상의 결 과에서 $\mathrm{T} 1$ 구의 배양액내 $\mathrm{pH}$ 는 대조구의 배양 액내 $\mathrm{pH}$ 와 전 배양시간에서 차이가 없는 것으 로 나타나 반추위액내에서 무기태 $\mathrm{Cr}$ 의 이용성 은 낮다고 판단되었다. 한편 $\mathrm{T} 2$ 구는 배양액내 $\mathrm{pH}$ 가 비록 통계적인 유의성은 없었으나, 전 배
양시간에서 대조구와 $\mathrm{T} 1$ 구에 비하여 상대적으 로 낮은 경향을 보였다. 이와 같은 결과는 배 양액내 낮은 $\mathrm{pH}$ 가 methionine의 부분적인 분해 로 인한 결과인지 혹은 크라민 ${ }^{\circledR}$ 의 첨가로 인한 반추위내 영양소 이용성이 향상되었기 때문에 일어난 현상인지에 대하여는 앞으로도 보다 많 은 연구가 이루어져야 할 것으로 사료된다.

반추위내에서 단백질 영양의 효과에 대한 지 표 중의 하나가 암모니아를 꼽을 수 있다. 반 추위 내에서 암모니아 농도는 사료 단백질의 이화작용, 반추위로부터 암모니아의 흡수 및 반추미생물의 성장으로 인한 암모니아의 동화 작용이 서로간의 균형을 나타낸다(엄 등, 2002). 따라서 본 실험에서도 반추위내 영양대사에서 중요한 위치를 차지하고 있는 암모니아 농도에 대해 조사하였는데, 그 결과는 Table 5에서 나 타낸 바와 같다. In vitro 배양 3 시간의 대조구, $\mathrm{T} 1$ 구 및 $\mathrm{T} 2$ 구의 배양액내 암모니아 농도는 각 각 $15.78,13.58$ 및 $17.04 \mathrm{mg} / \mathrm{dl}$ 로 대조구에 비 해 $\mathrm{T} 1$ 구의 경우에는 암모니아 농도가 낮게 나 타난 반면에 $\mathrm{T} 2$ 구의 경우에는 암모니아 농도가 유의적으로 높은 결과를 보였다 $(\mathrm{P}<0.05)$. 한편, 배양 0 시간부터 배양 6 시간까지는 처리에 관계 없이 배양액내 암모니아 농도가 증가하는 경향 을 보였으며, 대조구 및 $\mathrm{T} 1$ 구에 비해 $\mathrm{T} 2$ 의 암 모니아 생성량이 많은 것으로 나타났다. 반면 에 배양 6시간 이후에는 처리에 관계없이 배양 액내 암모니아 농도가 감소하여 일정 농도를 유지하는 결과를 보였다. 일반적으로 암모니아

Table 4. Changes of $\mathrm{pH}$ during in vitro incubation

\begin{tabular}{cccc}
\hline \multirow{2}{*}{ Incubation time $(\mathrm{hr})$} & \multicolumn{3}{c}{ Treatments } \\
\cline { 2 - 4 } & Control & $\mathrm{T} 1$ & $\mathrm{~T} 2$ \\
\hline \hline 0 & $6.81 \pm 0.13$ & $6.82 \pm 0.04$ & $6.80 \pm 0.07$ \\
6 & $6.61 \pm 0.14$ & $6.66 \pm 0.09$ & $6.59 \pm 0.05$ \\
9 & $6.30 \pm 0.13$ & $6.35 \pm 0.04$ & $6.25 \pm 0.10$ \\
12 & $6.11 \pm 0.08$ & $6.13 \pm 0.13$ & $6.03 \pm 0.05$ \\
\hline
\end{tabular}

$\mathrm{T} 1: \mathrm{CrCl}_{3} 1000 \mathrm{ppb}, \mathrm{T} 2$ : Chromium-methionine chelate $1000 \mathrm{ppb}$

${ }^{a b c}$ Means with different superscripts in the same row $\operatorname{differ}(\mathrm{P}<0.05)$. 
Table 5. Changes of ammonia concentration during in vitro incubation

\begin{tabular}{cccc}
\hline \multirow{2}{*}{ Incubation time(hr) } & \multicolumn{3}{c}{ Treatments } \\
\cline { 2 - 4 } & Control & $\mathrm{T} 1$ & $\mathrm{~T} 2$ \\
\hline \hline 0 & $8.45 \pm 0.24^{\mathrm{c}}$ & $11.60 \pm 0.02^{\mathrm{a}}$ & $10.29 \pm 0.06^{\mathrm{b}}$ \\
3 & $15.78 \pm 0.03^{\mathrm{b}}$ & $13.58 \pm 0.18^{\mathrm{c}}$ & $17.04 \pm 0.05^{\mathrm{a}}$ \\
6 & $15.88 \pm 0.08^{\mathrm{c}}$ & $16.89 \pm 0.09^{\mathrm{b}}$ & $21.20 \pm 0.04^{\mathrm{a}}$ \\
9 & $15.61 \pm 0.11^{\mathrm{a}}$ & $13.14 \pm 0.08^{\mathrm{c}}$ & $14.53 \pm 0.08^{\mathrm{b}}$ \\
12 & $11.70 \pm 0.01^{\mathrm{c}}$ & $12.51 \pm 0.07^{\mathrm{b}}$ & $14.55 \pm 0.00^{\mathrm{a}}$ \\
\hline
\end{tabular}

T1 : $\mathrm{CrCl}_{3} 1000 \mathrm{ppb}, \mathrm{T} 2$ : Chromium-methionine chelate $1000 \mathrm{ppb}$

${ }^{a b c}$ Means with different superscripts in the same row $\operatorname{differ}(\mathrm{P}<0.05)$

는 반추 미생물의 단백질 합성에 가장 중요한 질소원이며(Bryant, 1974), 사료내 단백질 함량 이나 용해도와 그 밖의 물리 및 화학적 특성에 따라 반추위내의 암모니아 농도는 크게 영향을 받게 되는데, Erdman 등(1985) 및 Church(1988) 는 반추위내의 암모니아 농도는 사료의 소화 속도와 어느 정도 일정한 경향을 나타낸다고 보고하여 본 실험에서도 in vitro 배양액의 $\mathrm{pH}$ 가 낮고 암모니아 농도가 높았던 $\mathrm{T} 2$ 가 대조구 및 $\mathrm{T} 1$ 구에 비해 미생물에 의한 암모니아 이용 성이 더 높은 것으로 판단된다. 따라서 유기태 $\mathrm{Cr}$ 첨가가 무기태 $\mathrm{Cr}$ 첨가에 비해 실제로 반추 가축에 있어서 반추위내 미생물체 단백질 합성 을 위한 더 많은 질소원을 제공할 수 있다고 판단되었다.

$\mathrm{Cr}$ 원료의 첨가에 따른 in vitro 배양액의 휘 발성지방산(VFA) 농도 변화는 Table 6의 결과 와 같다. In vitro 배양시간에 따른 총 휘발성 생성량(TVFA)은 처리에 관계없이 배양 시간이 경과함에 따라 지속적으로 증가하는 경향을 보 였으며, 배양 12 시간을 제외한 전 배양시간에 서 대조구에 비해 처리구들( $\mathrm{T} 1$ 및 $\mathrm{T} 2$ 구)의 TVFA가 유의적으로 낮은 것으로 나타났다 $(\mathrm{P}<0.05)$. 한편 in vitro 배양 12 시간의 대조구, $\mathrm{T} 1$ 및 $\mathrm{T} 2$ 구의 배양액내 acetate 농도는 각각 $53.78,54.11$ 및 $50.18 \mathrm{mM} / \mathrm{dl}$ 로 대조구 및 $\mathrm{T} 1$ 구 에 비해 $\mathrm{T} 2$ 구의 배양액내 acetate 농도가 낮게 나타났으며, 이로 인해 $\mathrm{T} 2$ 구의 $\mathrm{A} / \mathrm{P}$ ratio가 낮
은 결과를 보였다. 이와 같이 $\mathrm{A} / \mathrm{P}$ ratio 변화는 반추동물의 생체내에서 일어나는 VFA 이용 및 그 생리적 작용을 변화시켜 지방대사를 조절하 기 때문에 최근에는 이를 이용하여 고급육 생 산에 응용하려고 노력하고 있다(Hiroaki, 1997).

In vitro 배양 동안 배양액내의 총 미생물의 건물 회수율은 Table 7과 같다. In vitro 배양 12 시간 동안의 대조구의 총 미생물의 건물 회 수율은 모든 처리구간 통계적인 차이는 없었으 나, $0.42 \%$ 에서 $0.51 \%$ 로 약 $12 \%$ 증가하였고, $\mathrm{T} 1$ 구는 $0.43 \%$ 에서 $0.49 \%$ 로 경미한 증가를 보였으 나, $\mathrm{T} 2$ 구의 경우에는 $0.45 \%$ 에서 $0.66 \%$ 로 약 $15 \%$ 증가하는 것으로 나타난 것으로 미루어 크라민 ${ }^{\circledR}$ 의 첨가로 인해 미생물 건물량이 효율 적으로 증가된 것으로 판단된다. 일반적으로 반추위에서 소장으로 유입되는 단백질의 60 $80 \%$ 가 반추위에서 합성된 미생물 단백질로 구 성되며(Smith, 1979), 이러한 미생물 단백질 소 화율은 $70 \%$ 이상으로 반추위에서 합성되는 미 생물 단백질은 숙주동물에게 단백질 공급원으 로서 중요한 역할을 담당하고 있다. 한편, 반추 위내 암모니아의 경우 반추미생물의 단백질 합 성에 영향을 미치는 요인 중의 하나인 동시에 반추위내 미생물 성장을 위한 필수적인 질소원 인데(Stern 등, 1978), 본 실험의 결과에서 크라 민 ${ }^{\circledR}$ 의 첨가로 인해 반추위 미생물 건물 회수량 이 증가한 원인은 크라민 ${ }^{\circledR}$ 의 첨가가 배양액내 암모니아의 생성량을 증가시킨 것이 그 원인으 
Table 6. Changes of volatile fatty acids during in vitro incubation

\begin{tabular}{|c|c|c|c|c|}
\hline \multirow{2}{*}{$\begin{array}{l}\text { Incubation } \\
\text { time(hr) }\end{array}$} & \multirow{2}{*}{ Items } & \multicolumn{3}{|c|}{ Treatments } \\
\hline & & Control & $\mathrm{T} 1$ & $\mathrm{~T} 2$ \\
\hline \multirow{5}{*}{0} & Acetic $\operatorname{acid}(\mathrm{C} 2)$ & $21.28 \pm 1.34$ & $20.73 \pm 0.79$ & $21.46 \pm 1.45$ \\
\hline & Butyric acid(C4) & $2.30 \pm 0.19$ & $2.45 \pm 0.06$ & $2.64 \pm 0.11$ \\
\hline & Propionic acid(C3) & $3.80 \pm 0.36$ & $4.06 \pm 0.14$ & $4.21 \pm 0.04$ \\
\hline & TVFA & $27.38 \pm 0.80$ & $27.23 \pm 0.61$ & $28.32 \pm 1.55$ \\
\hline & $\mathbf{A} / \mathbf{P}$ ratio & 5.60 & 5.11 & 5.10 \\
\hline \multirow{5}{*}{3} & Acetic $\operatorname{acid}(\mathrm{C} 2)$ & $30.73 \pm 7.85^{\mathrm{a}}$ & $27.76 \pm 5.76^{\mathrm{c}}$ & $29.39 \pm 6.90^{b}$ \\
\hline & Butyric $\operatorname{acid}(\mathrm{C} 4)$ & $3.94 \pm 1.00^{\mathrm{a}}$ & $3.52 \pm 0.71^{\mathrm{b}}$ & $3.80 \pm 0.90^{\mathrm{a}}$ \\
\hline & Propionic $\operatorname{acid}(\mathrm{C} 3)$ & $8.57 \pm 3.06^{\mathrm{a}}$ & $7.50 \pm 2.31^{\mathrm{b}}$ & $8.54 \pm 3.05^{\mathrm{a}}$ \\
\hline & TVFA & $43.24 \pm 11.91^{\mathrm{a}}$ & $38.78 \pm 8.78^{\mathrm{c}}$ & $41.73 \pm 10.84^{\mathrm{b}}$ \\
\hline & A/P ratio & $3.58 \pm 0.34$ & $3.70 \pm 0.21$ & $3.44 \pm 0.12$ \\
\hline \multirow{5}{*}{6} & Acetic $\operatorname{acid}(\mathrm{C} 2)$ & $43.86 \pm 17.13^{\mathrm{a}}$ & $38.54 \pm 13.48^{\mathrm{b}}$ & $41.30 \pm 15.32^{\mathrm{ab}}$ \\
\hline & Butyric acid(C4) & $5.57 \pm 2.15^{\mathrm{a}}$ & $4.75 \pm 1.57^{\mathrm{c}}$ & $5.10 \pm 1.82^{\mathrm{b}}$ \\
\hline & Propionic acid(C3) & $16.74 \pm 8.84^{\mathrm{a}}$ & $14.65 \pm 7.36^{\mathrm{b}}$ & $16.62 \pm 8.76^{\mathrm{a}}$ \\
\hline & TVFA & $66.18 \pm 28.13^{\mathrm{a}}$ & $57.94 \pm 22.37^{\mathrm{c}}$ & $63.02 \pm 25.90^{\mathrm{b}}$ \\
\hline & A/P ratio & $2.62 \pm 0.12$ & $2.63 \pm 0.08$ & $2.48 \pm 0.18$ \\
\hline \multirow{5}{*}{9} & Acetic $\operatorname{acid}(\mathrm{C} 2)$ & $52.56 \pm 23.29^{\mathrm{a}}$ & $47.56 \pm 19.75^{\mathrm{c}}$ & $49.96 \pm 21.46^{\mathrm{b}}$ \\
\hline & Butyric $\operatorname{acid}(\mathrm{C} 4)$ & $7.01 \pm 3.17^{\mathrm{a}}$ & $6.11 \pm 2.53^{\mathrm{b}}$ & $6.54 \pm 2.85^{\mathrm{b}}$ \\
\hline & Propionic $\operatorname{acid}(\mathrm{C} 3)$ & $21.84 \pm 12.45^{\mathrm{a}}$ & $20.72 \pm 11.66^{\mathrm{b}}$ & $21.18 \pm 11.98^{\mathrm{ab}}$ \\
\hline & TVFA & $81.42 \pm 38.91^{\mathrm{a}}$ & $74.39 \pm 33.93^{\mathrm{c}}$ & $77.68 \pm 36.29^{b}$ \\
\hline & A/P ratio & $2.41 \pm 0.21$ & $2.30 \pm 0.26$ & $2.36 \pm 0.09$ \\
\hline \multirow{5}{*}{12} & Acetic $\operatorname{acid}(\mathrm{C} 2)$ & $53.78 \pm 24.18$ & $54.11 \pm 24.45$ & $50.18 \pm 25.84$ \\
\hline & Butyric acid(C4) & $7.91 \pm 3.80$ & $7.56 \pm 3.57$ & $7.79 \pm 3.73$ \\
\hline & Propionic $\operatorname{acid}(\mathrm{C} 3)$ & $22.80 \pm 13.14$ & $21.44 \pm 14.30$ & $21.41 \pm 12.15$ \\
\hline & TVFA & $84.48 \pm 41.12$ & $83.05 \pm 42.32$ & $79.58 \pm 41.71$ \\
\hline & $\mathbf{A} / \mathbf{P}$ ratio & $2.36 \pm 0.15$ & $2.52 \pm 0.18$ & $2.34 \pm 0.17$ \\
\hline
\end{tabular}

$\mathrm{T} 1: \mathrm{CrCl}_{3} 1000 \mathrm{ppb}, \mathrm{T} 2:$ Chromium-methionine chelate $1000 \mathrm{ppb}$

${ }^{a b c}$ Means with different superscripts in the same row $\operatorname{differ}(\mathrm{P}<0.05)$

TVFA : Total Volatile Fatty Acid, A/P ratio : Acetic acid/Propionic acid.

로 판단되며, 실제로 본 실험에서 배양액내 암 모니아(Table 5) 농도가 대조구 및 $\mathrm{T} 1$ 구에 비해 $\mathrm{T} 2$ 구가 대부분의 배양시간에서 높게 나타난 사 실로 미루어도 이러한 결과를 뒷받침 해주고 있다고 판단할 수 있다.

총미생물 건물 중의 $\mathrm{Cr}$ 함량은 Table 8 에 나 타낸 바와 같다. 각 처리 간 $\mathrm{Cr}$ 함량은 in vitro 배양 초기에는 차이를 보이지 않았으나(P>
$0.05)$, 배양 3 시간 째 미생물 내 $\mathrm{Cr}$ 함량이 대 조구, $\mathrm{T} 1$ 및 $\mathrm{T} 3$ 에서 각각 $148.3,192.0$ 및 165.0 $\mathrm{ppb}$ 로 나타났다. 이와 같이 대조구의 경우에는 배양 0 시간에 비해 $\mathrm{Cr}$ 함량이 다소 낮아졌으 나, $\mathrm{T} 1$ 및 $\mathrm{T} 2(\mathrm{P}<0.05)$ 구의 경우에는 $\mathrm{Cr}$ 함량이 배양 초기에 비하여 높아지는 결과를 보였다. 그러나 그 이후 배양시간이 경과함에 따라 $\mathrm{T} 1$ 구의 $\mathrm{Cr}$ 함량은 배양시간이 경과함에 따라 유 
Table 7. Dry matter recovery into rumen microbes during in vitro incubation

\begin{tabular}{cccc}
\hline \multirow{2}{*}{ Incubation time $(\mathrm{hr})$} & \multicolumn{3}{c}{ Treatment } \\
\cline { 2 - 4 } & $\ldots \ldots \ldots \ldots \ldots \ldots \ldots \ldots \ldots \ldots$ & $\mathrm{T} 1$ & $\mathrm{~T} 2$ \\
\hline \hline & & Control & of DM recovery $\ldots \ldots \ldots \ldots \ldots \ldots \ldots \ldots \ldots \ldots$ \\
3 hour & $0.42 \pm 0.02$ & $0.43 \pm 0.03$ & $0.45 \pm 0.04$ \\
6 hour & $0.43 \pm 0.01$ & $0.43 \pm 0.02$ & $0.46 \pm 0.02$ \\
9 hour & $0.44 \pm 0.01$ & $0.44 \pm 0.03$ & $0.50 \pm 0.01$ \\
12 hour & $0.48 \pm 0.02$ & $0.43 \pm 0.03$ & $0.59 \pm 0.01$ \\
Total & $0.51 \pm 0.02$ & $0.49 \pm 0.02$ & $0.66 \pm 0.02$ \\
\hline
\end{tabular}

T1 : $\mathrm{CrCl}_{3} 1000 \mathrm{ppb}, \mathrm{T} 2$ : Chromium-methionine chelate $1000 \mathrm{ppb}$

${ }^{a b c}$ Means with different superscripts in the same row $\operatorname{differ}(\mathrm{P}<0.05)$

Table 8. Changes of $\mathrm{Cr}$ contents in rumen microbes during in vitro incubation.

\begin{tabular}{cccc}
\hline \multirow{2}{*}{ Incubation time $(\mathrm{hr})$} & \multicolumn{3}{c}{ Treatment } \\
\cline { 2 - 4 } & Control & $\mathrm{T} 1$ & $\mathrm{~T} 2$ \\
\hline \hline 0 & $156.75 \pm 2.65$ & $162.00 \pm 0.00$ & $159.00 \pm 6.32$ \\
3 & $148.30 \pm 4.25^{\mathrm{b}}$ & $192.00 \pm 8.16^{\mathrm{a}}$ & $165.00 \pm 3.84^{\mathrm{b}}$ \\
6 & $150.00 \pm 6.13^{\mathrm{b}}$ & $276.25 \pm 7.16^{\mathrm{a}}$ & $162.88 \pm 2.35^{\mathrm{b}}$ \\
9 & $156.30 \pm 3.76^{\mathrm{b}}$ & $253.38 \pm 7.12^{\mathrm{a}}$ & $169.75 \pm 6.54^{\mathrm{b}}$ \\
12 & $147.65 \pm 9.07^{\mathrm{b}}$ & $230.50 \pm 7.08^{\mathrm{a}}$ & $155.38 \pm 8.27^{\mathrm{b}}$ \\
\hline
\end{tabular}

$\mathrm{T} 1: \mathrm{CrCl}_{3} 1000 \mathrm{ppb}, \mathrm{T} 2$ : Chromium-methionine chelate $1000 \mathrm{ppb}$

${ }^{a b c}$ Means with different superscripts in the same row $\operatorname{differ}(\mathrm{P}<0.05)$.

의적으로 높게 나타난 반면에 대조구와 $\mathrm{T} 2$ 구의 $\mathrm{Cr}$ 함량은 비슷한 수준을 유지하였다. 한편, $\mathrm{T} 2$ 구의 $\mathrm{Cr}$ 함량이 대조구에 비하여 약간 높은 것 은 미결합 $\mathrm{Cr}$ 분자가 미생물에 이용되었을 가 능성을 제기할 수 있으며, 본 시험의 결과만으 로는 크라민 ${ }^{\circledR}$ 이 반추 미생물에 의해 분해되는 것은 상당히 미약할 것이라고 판단된다.

총미생물 건물 중의 미생물체를 분석한 결 과, 미생물체 내 methionine 및 cystein 함량을 분석한 결과는 Fig. 1에서 나타낸 바와 같다. 통계적인 차이는 나타나지 않았으나, 미생물체 내에 methionine 농도는 배양 시간이 경과함에 따라 계속적으로 증가하는 경향을 보였으나, cystein의 경우에는 배양시간의 경과에 따른 변
화는 없는 것으로 나타났다. 또한 각 배양 시 간대별 methionine 농도는 처리 간에 차이 $(\mathrm{P}<0.05)$ 가 없는 것으로 나타났으며, 오히려 대 조구의 methionine 농도가 높게 나타난 점으로 미루어 반추 미생물에 의한 크라민 ${ }^{\circledR}$ 의 분해는 극히 제한적인 것으로 판단된다.

따라서 본 시험의 결과를 종합해보면, 크라 민 ${ }^{\circledR}$ 의 첨가에 따른 in vitro 배양액내 $\mathrm{pH}$ 및 암 모니아 농도를 포함한 발효특성에 대한 부의 영향은 없는 것으로 판단되며, 오히려 미생물 체 단백질의 합성에 이용되어 숙주동물을 단백 질 공급원으로 이용될 수 있는 암모니아의 생 성량과 총미생물 건물회수량을 증가시킬 수 있 는 것으로 판단된다. 또한 총미생물 건물 중의 
Fig. 1. Changes of methionine and cysteine concentration in rumen microbes during in vitro incubation.

$\mathrm{T} 1: \mathrm{CrCl}_{3} 1000 \mathrm{ppb}$.

T2 : Chromium-methionine chelate $1000 \mathrm{ppb}$. Met: Methionine, Cys : Cysteine.

$\mathrm{Cr}$ 및 methionine 함량 분석을 통해서 확인된 바와 같이 반추 미생물에 의한 크라민 ${ }^{\circledR}$ 의 분해 는 상당히 제한적이기 때문에 실제로 반추가축 에 급여하였을 경우 반추위 분해를 회피해서 소장으로 by-pass 되어 숙주동물에서 $\mathrm{Cr}$ 의 이용 성 증진에 도움이 될 수 있을 것으로 판단된 다.

\section{IV. 요 약}

본 연구는 무기태 크롬 $\left(\mathrm{ClCl}_{3}\right)$ 와 유기태화 크 롬인 Cr-methionine chelate(크라민 $\left.{ }^{\circledR}\right)$ 을 첨가하였 을 때 in vitro 조건에서 반추위내 발효성상과 반추미생물체 내 $\mathrm{Cr}$ 과 Methionine을 분석하여 크라민 ${ }^{\circledR}$ 의 by-pass 여부를 간접적으로 증명하고 자 실시하였다.

In vitro 소화시험에 이용한 기초영양소는 Jar 당 반추미생물 기초 영양소로 시중에 유통되고 있는 배합사료 $7 \mathrm{~g}(\mathrm{DM})$, 볏짚 $2 \mathrm{~g}(\mathrm{DM})$ 및 Corn silage $2 \mathrm{~g}(\mathrm{DM})$ 을 동일하게 배합하였으며, 시험구로는 대조구 (control), $\mathrm{CrCl}_{3}$ 를 $1000 \mathrm{ppb}$ 첨가한 $\mathrm{T} 1$ 구 및 $\mathrm{Cr}$ 농도가 $1000 \mathrm{ppb}$ 이 되도록 크라민 ${ }^{\circledR}$ 을 첨가한 $\mathrm{T} 2$ 구를 두었으며, 처리 당 5 반복으로 시험을 수행하였다.

$\mathrm{T} 2$ 의 $\mathrm{pH}$ 는 모든 배양시간에서 대조구 및 $\mathrm{T} 1$ 구에 비하여 낮은 경향을 보였으며, 암모니아 농도는 배양 6 시간 전까지는 대조구와 $\mathrm{T} 1$ 구에
비하여 T2구가 높은 경향을 보였으나, 배양 6 시간 이후에는 모든 처리구가 일정하게 낮게 유지되었다. 총 휘발성지방산 농도는 모든 처 리구가 배양시간이 경과함에 다라 지속적으로 증가하였으며, 대조구에 비하여 $\mathrm{T} 1$ 구와 $\mathrm{T} 2$ 구의 농도가 유의적으로 낮았다. In vitro 배양 12시 간 동안 미생물체 건물 회수율은 $\mathrm{T} 1$ 구가 가장 낮은 반면에 $\mathrm{T} 2$ 구가 가장 효율적으로 미생물을 증가시켰다. 반추미생물체 내 $\mathrm{Cr}$ 농도는 대조 구와 $\mathrm{T} 2$ 구간에는 차이가 없었으나 $(\mathrm{P}>0.05), \mathrm{T} 1$ 구는 유의적 $(\mathrm{P}>0.05)$ 으로 높게 나타났다. 반추 미생물체 내 methionine 및 cyctine 농도는 대조 구와 $\mathrm{T} 2$ 구간에는 차이 $(\mathrm{P}>0.05)$ 가 없었으나, $\mathrm{T} 1$ 구는 비교적 낮은 경향을 보였다.

본 시험의 결과를 종합해 보면, 크라민 ${ }^{\circledR}$ 의 첨가에 따른 in vitro 배양액내 $\mathrm{pH}$ 및 암모니아 농도를 포함한 발효특성에 대한 부의 영향은 없는 것으로 판단되며, 오히려 미생물체 단백 질의 합성에 이용되어 암모니아의 생성량과 총 미생물 건물 회수량을 증가시킬 수 있는 것으 로 판단된다. 또한 크라민 ${ }^{\circledR}$ 은 반추 미생물에 의해 상당히 제한적으로 분해되기 때문에 반추 위를 회피해서 소장으로 by-pass 되어 이용된 것으로 판단되었다.

\section{$\mathrm{V}$. 인 용 문 헌}

1. Anderson, R. A. 1988. Chromium. In: Smith, K. (Ed.), Trace elements in Food. Marcel Dekker, New York. pp. 231-247.

2. Bryant, M. P. 1974. Nutritional features and ecology of predominant anaerobic bacteria of the intestinal tract. Am. J. Clin. Nutr. 27:1313.

3. Chang, X. and Mowat, D. N. 1992. Supplemental chromium for stressed and growing feeder calves. J. Anim. Sci. 70:559.

4. Church, D. C. 1988. The ruminant animal. Digestive physiology and nutrition. Prentice Hall. Englewood Cliffs. New Jersey.

5. Erdman, R. A. 1985. Effect of abomasal and dietary choline on milk yield and composition in first lactation dairy cows. J. Dairy Sci. 68:134 (Abstr.). 
6. Evans, G. W. 1989. The effect of chromium picolinate om insulin controlled parameters in humans. Int. J. Biosocial. Med. Research. 11:163180.

7. Hiroaki, S. 1997. Control of Secretion and Action of Insulin by Volatile Fatty Acids in Ruminants. Animal Sci. and Technol. (Jpn). 68:993-1002.

8. Jeffrey, A. and Fisher, M. D. 1990. The Chromium Program. New York, 1-5.

9. Kegley, E. B., Spears, J. W. and Jr. Brown, T. T. 1997. Effect of shipping and Chromium Supplementation on performance, Immune Response, and Disease Resistance of Steers. 75:1956-1964.

10. Mason, V. C., Bach, A. S. and Rudeom, M. 1980. Hydrolysate prepararation for amino acids determinations in feed constituents. 3rd EAAPSymposium on protein metabolism and nutrition. Braunchweig.

11. Mertz, W. and Roginski, E. E. 1969. Effects of chromium(III) supplementation on growth and survival under stress in rats fed low protein diets. J. Nutr. 97:531.

12. Moonsie-shageer and Mowat, D. N. 1993. Effect of level of supplemental chromium on performance, serum constituents and immune status of stressed feeder calves. J. Anim. Sci. 71:232-238.

13. Page, T. G., Southern, L. L., Ward, T. L. and Thompson, Jr. D. L. 1993. Effect of chromium picolinate on growth and serum and carcass traits of growing-finishing pig. J. Anim. Sci. 71:656.

14. SAS. 1990. SAS/STAT guide for personal computers@6.08. SAS Institute Inc. Cary, USA.

15. Shultz, T. A. and Shultz, E. 1970. Estimation of rumen microbial nitrogen by three analytical methods. J. Dairy Sci. 53:781-784.

16. Shwartz, K. and Merts, W. 1959. Chromium(III) and the glucose tolerance factor. Arch. Biochem. Biophys. 72:515-518.

17. Smith, R. H. 1979. Synthesis of microbial nitrogen compounds in the rumen and their subsequent digestion. J. Anim. Sci. 49(6):1604.

18. Steele, N. C., Althen, T. G. and Frobish, L. T. 1977. Biological activity of glucose tolerance factor in swine. J. Anim. Sci. 45:1341.

19. Stern, M. D., Hoover, W. H. and Crooker, P. H. 1978. Effects of nonstructural carbohydrate, urea and soluble protein synthesis in continuous culture of rumen contents. J. Anim. Sci. 47:944.

20. Swanson, K. C., Harmon, D. L., Jacques, K. A., Larson, B. T., Richards, C. J., Bohnert, D. W. and Paton, S. J. 2000. Efficacy of chromium-yeast supplementation for growing beef steers. 86:95105.

21. Votava, H. J., Hahn, C. J. and Evans, G. W. 1973. Isolation and partial characterrization of a ${ }^{51} \mathrm{Cr}$ complex from brewer's yeast. Biochem. Biophys. Res. Commun. 55:312.

22. 박병기, 박재인, 라창식, 신종서. 2002. 폐기균체 의 재활용에 관한 연구. 강원대학교 동물자원공 동연구소 논문집 동물자원연구. 13:166-175.

23. 엄창국, 박병기, 박재인, 김창혁, 고용균, 김종복, 홍병주, 신종서. 2002. 알코올 발효사료 급여가 반추위내 발효성상 및 미생물 단백질 합성에 미 치는 영향. 강원대학교 동물자원공동연구소 논문 집 동물자원연구. 13:207-219.

(접수일자 : 2005. 5. 17. / 채택일자 : 2005. 8. 10.) 